\title{
Protection of Migrant Workers in Suriname: How do Indonesian Representatives Implement International Labour Organization Conventions?
}

\author{
Lutecia Zahra Maharani Wibisono* \\ Faculty of Law, Universitas Pembangunan Nasional Veteran, Jakarta, Indonesia
}

\section{Diani Sadiawati**}

Faculty of Law, Universitas Pembangunan Nasional Veteran, Jakarta, Indonesia

\begin{abstract}
In June 2020, sixteen Indonesian migrant workers (IMW) who worked as fishing boat crew in a Surinamese company fled to the Indonesian Embassy in Paramaribo, Suriname to acquire protection and assistance. They revealed that the company had failed to uphold their rights, committed inhuman treatment, and resulted in numerous losses. The embassy then immediately exercised a consular function to protect their safety and tried to facilitate the demands of those sailors to relevant parties and local authorities. The article aims to analyze the role of Indonesian representatives to protect the rights of Indonesian migrant workers in Suriname based on the International Labour (LO) conventions. It is juridical empirical research that was conducted through visiting and field research to the Indonesian Embassy in Suriname in November 2020. The research suggested that Indonesian representatives in Suriname have played a significant role in advocating the IMW rights through all possible means, including mediation, negotiation, and diplomatic channels. In addition, there is a need to create a Memorandum of Understanding between Indonesia and Suriname to ensuring proper protection for migrant workers.
\end{abstract}

Keywords: Protection; Migrant worker; Suriname; Indonesian representatives, International Labour Organizations conventions.

\section{INTRODUCTION}

\subsection{Background}

Suriname is the country where around 700 Indonesian Migrant Workers (IMW) are working, reflecting the highest number of IMW in the South America region. There is not much information available to the public about how their situation there. When this research was conducted, it can be revealed that some of IMW had unpleasant experienced when working in some companies in Suriname including got financial losses and psychological disorders and even attempted to commit suicide. ${ }^{1}$

This article highlights a case that occurred in 2020 when 16 Indonesian fishing boat crew (FBC) ran away from a company, initialized

\footnotetext{
** Email/Corresponding Author: luteciawibisonø@upnvj.ac.id

** Email : diani@bappenas.go.id

1 Michael Bastian Supit, Head of Protocol \& Consular, Indonesia Embassy in Paramaribo-Suriname, "Protection of Migrant Workers in Suriname: How do Indonesian Representatives Implement ILO Conventions?" Interview by Lutecia Wibisono in Paramaribo-Suriname, December 18, 2020.
} 
CF. ${ }^{2}$ Those sailors argued that the company had failed to uphold their rights, committed inhuman treatment, and resulted in numerous losses. Therefore, they demanded the CF to pay their salary and fulfill their rights. The Indonesian Embassy in Paramaribo, Suriname immediately exercised a consular function by taking appropriate action, including brought the case to the attention of the Surinamese government to jointly resolve the case. ${ }^{3}$

It is a general practice that Indonesian representatives abroad request IMW to make a report on their travel documents (e.g passports), personal data, and employment contracts. This is conducted to provide protection and to avoid risks of IMW in the country where they are employed. It is also a procedural standard that IMW protection is given from the recruitment process until the return to Indonesia. Since the beginning, IMW is encouraged to complete the basic and required documents to prevent possible risks when they arrive and work in designated countries. ${ }^{4}$

What occurred in the present case is that the 16 seamen who work at $\mathrm{CF}$ did not report themselves to the Indonesian Embassy in Paramaribo, Suriname. Besides, the agent (PJTKI) and Indonesian Migrant Workers Placement (P3MI), formerly known as the Indonesian Migrant Worker Placement and Service Centre (BP2TKI), did not contact the embassy and provide an official report of their seafarers working in Suriname. This leads to the lack of ability of the embassy to monitor the presence of those IMW in Suriname. Whatsoever, when IMW faces a problem abroad, the Indonesian government, through its official representatives, has a responsibility to take action. ${ }^{5}$

The authority of the Indonesian Embassy is limited by international law and the jurisdiction of the receiving state, that in this case, the Suriname government. The Indonesian national law that guarantees the rights of IMWs cannot be directly applied in Suriname, because Suriname has established its national law to be effectively enforced in its territory. Therefore, the next issue is on how the Indonesian Embassy applies international law, especially relevant treaties, to dealing with the case in concern.

Considering International Labour Organization (ILO) is an international organization that deals with the issue of migrant workers, the rights and protections of 16 IMW, in this case, may be analyzed by looking at relevant ILO conventions. ILO is a United Nations agency that brings together governments, employers, and workers of 187 member states, aims to set labour standards, develop policies and devise programs promoting

\footnotetext{
${ }^{2}$ Name of the company initialized in honor to protect and respect their reputation.

${ }^{3}$ Supit, loc.cit.

4 See Deny Tri Wahyudi, "Perlindungan Hukum Terhadap Tenaga Kerja Indonesia Di Luar Negeri", Jurnal Imu Hukum, (2015): 170-184. doi: https:// doi.org/10.30996/mk.v0i0.2118

5 See Koesrianti. "Perlindungan Hukum Pekerja Migran PLRT Di Luar Negeri Oleh Negara Ditinjau Dari Konsep Tanggung Jawab Negara", Yustitia 4, No. 2 (2015): 247-288.
} 
decent work for all women and men. The ILO has a mission to investigate, promote, or support the creation of chances for migrant workers or employees who work abroad to acquire decent work for their rights in a free, fair, and secure manner. In this sense, the ILO Convention aims to improve employees' rights at work, increase social protection, and strengthen discourse to address issues relating to the world of workers. ${ }^{6}$ The ILO works to forge policies to maximize the benefits of labour migration for all those involved. ${ }^{7}$ Both Indonesia and Suriname are a member of the ILO. One side, Indonesia is a member of ILO since 12 May 1950 and until the present has ratified 20 ILO conventions, ${ }^{8}$ while Suriname has become an ILO member since 24 February 1976 and currently has ratified 33 ILO conventions along with 1 protocol. 9 The ILO's policy on active partnerships has the objective of unifying the ILO with tripartite elements in member countries and continuously improving the technical services program. Special assistance is provided to workers within the framework of an active partnership policy. The priority of the active partnership is the provision of technical assistance and advice in the application of international labor standards, in particular the ILO basic conventions on human rights. ${ }^{10}$

\subsection{Research Problem}

In general, this article aims to analyze the role of the Indonesian Embassy in Paramaribo, Suriname to protect the rights of Indonesian migrant workers based on the International Labour Organisation (ILO) conventions. In specific, this research article formulates 3 (three questions). First, how is the detail of the case involving the 16 Indonesian fishing boat crew who fled from the company they worked? Second, how is the function of Indonesian representatives to protect Indonesian migrant workers in Suriname? Lastly, how ILO conventions may be used as a legal instrument to advocate the rights of those Indonesian fishermen?

\footnotetext{
6 International Labour Organization "ILO Global" http://www.ilo.org/global/What_we_do/Publications/lang--en/contLang-id/docName WCMS_098256/ index.htm.

International Labour Organization, "Labour Migration", https:/ / www.ilo.org/global/topics/labour-migration/lang--en/index.htm

8 International Labour Organization, Normlex, Ratification by Country, "Ratifications for Indonesia".

https:/ / www.ilo.org/dyn/normlex/en/f?p=1000:11200:0::NO:11200:P11200_COUNTRY_ID $: 102938$ for

${ }^{9}$ International Labour Organization, Normlex, Ratification by Country, "Ratifications https:/ / www.ilo.org/dyn/normlex/en/f?p=1000:11200:0::NO:11200:P11200_COUNTRYID $\frac{: 103287}{10}$

Labour

Organization,

"What We

Do"

http://www.ilo.org/global/What_we_do/Publications/lang--en/contLang--id/docName WCMS_098256/index.htm
} 


\subsection{Method}

This article is written based on juridical-empirical research. The primary data is collected from a visiting and field research to the Indonesian Embassy in Paramaribo, Suriname on 6 November 2020 that resulted in a set of documents and reports as well as information obtained from an interview. Secondary data consists of primary legal sources in form of treaties and national law and regulations as well as additional sources in form of textbooks, journal articles, newspapers, and online sources.

\subsection{Conceptual Framework}

This paper is conceived to identify the legal protection of Indonesian migrant workers, the role of Indonesian representatives in protecting migrant workers, and more specific, the role of the international labor organization (ILO) in protecting Indonesian migrant workers

It is necessary to have a protection that can overcome existing problems related to the placement and protection of IMW before leaving, during work, or after returning to Indonesia. ${ }^{11}$ The right to work is part of human rights and therefore State is encouraged to play an active role in protecting its citizens' rights. ${ }^{12}$ Legal protection is all efforts to fulfill rights and provide assistance to provide a sense of security to witnesses and/or victims. ${ }^{13}$ This legal protection is essential for IMW who work overseas due to the lack of job opportunities in Indonesia. In specific, the Indonesian government should provide protection and assistance to ensure fair wages as well as equal and non-abusive treatments, are given to IMW by the company where they work.

To achieve that aim, three strategies could be used to protect migrant workers, namely: (1) prevention, (2) early detention, (3) immediate response. These strategies may also be used by Indonesian Representatives to always be ready in facilitating the fulfillment of IMW's rights. In the placement period, the protection may include a. Guidance and supervision; $b$. Assistance and consular protection; c. The provision of legal aid; d. The advocating on the fulfillment of the rights of migrant workers; e. Protection and other assistance in accordance with the provisions of the legislation as well as international law and practice; and f. Diplomatic efforts. ${ }^{14}$ As can be observed in the fields, the Indonesian Representatives give an immediate

11 A.A. Titah Ratihtiari and I Wayan Parsa, "Perlindungan Hukum Terhadap Pekerja Migran Indone sia Di Luar Negeri". Kertha Semaya 7, No. 7 (2019) : 4.

doi: https://ojs.unud.ac.id/index.php/kerthasemaya/article/view/50129/29846

12 See The 1945 Constitution of the Republic of Indonesia, Art. 28D paragraph (2). See also Lukas Banu, "Implementasi Hukum Pasal 35 UU No. 39 Tahun 2004 dalam Program Recognized Seasonal Employment", Jurnal Magister Hukum Udayana 7, No. 1 (2018): 92 doi: https://doi.org/10.24843/JMHU.2018.v07.i01.p08.

13 Soerjono Soekanto, Pengantar Penelitian Hukum (Jakarta: UI Press, 1984): 133.

14 Henni Wijayanti and Arovah Windiani. "Legal Protection and Advocacy for Indonesian Migrant Workers", Jurnal Universitas Muhammadiyah 1, No. 1 (2017): 1005 doi: https://jurnal.umj.ac.id/index.php/IMC/article/view/1300/1171 
response in case IMW has trouble with the company, in particular with regards to an employment relationship, due to various factors.

At the international level, ILO conventions were established to promote and ensure the fulfillment of the rights of migrant workers. ILO also works with governments in various countries to campaign the importance of ratifying the International Convention on the Protection of the Rights of All Migrant Workers and Members of Their Families. ${ }^{15}$ ILO supported the Indonesian Government to develop and strengthen policies and plans for IMW. 16

\section{RESULT AND ANALYSIS}

\subsection{The Flee of Indonesian Migrant $W$ orkers}

On 3 June 2020, sixteen (16) IMW who worked as FBC in a foreign company fled to the Indonesian Embassy to acquire protection and assistance. They were received by the Ambassador and the Head of Consular Affairs and were heard about their problems with CF, an initial of the company where they work. ${ }^{17}$ Data regarding the name, employment agent, amount of salary, job division, and duration of work are listed in Table 1.

Table 1

List of Seamen ${ }^{18}$

\begin{tabular}{llllll}
\hline No & $\begin{array}{l}\text { Name } \\
\text { Initial }\end{array}$ & Agent & $\begin{array}{l}\text { Amount } \\
\text { of Salary } \\
\text { per } \\
\text { month } \\
\text { (in USD) }\end{array}$ & $\begin{array}{l}\text { Position/Job } \\
\text { Divison }\end{array}$ & $\begin{array}{l}\text { Duration } \\
\text { of Work } \\
\text { (month) }\end{array}$ \\
\hline 1 & A. W & BPM & 600.00 & Oiler & 4 \\
\hline 2 & A. A & BPM & 450.00 & Deck & 4 \\
\hline 3 & N. R & BPM & 600.00 & Oiler & 4 \\
\hline 4 & Y. A. W & BPM & 450.00 & Deck & 4 \\
\hline 5 & A. H & GSJST & 600.00 & Oiler & 13 \\
\hline 6 & A. W & GSJST & 600.00 & Oiler & 13 \\
\hline
\end{tabular}

15 Office of the United Nations High Commissioner for Human Rights, "Status Of Ratification Interactive Dashboard," International Convention on the Protection of the Rights of All Migrant Workers and Members of their Families, https://indicators.ohchr.org/

16 Cici Valensy, "Peran International Labor Organization (ILO) Dalam Melindungi Buruh Migran Indonesia di Arab Saudi Tahun 2012-2016, Jurnal Online Mahasiswa FISIP 4 No. $\quad 2, \quad$ (2017): $6 . \quad$ doi: https:/ /jom.unri.ac.id/index.php/JOMFSIP/article/view/16335/15800

17 Data obtained from the Indonesian Embassy in Paramaribo, Suriname on December 18, 2020

18 Supit, loc.cit. The name of the sixteen Indonesian migrant workers and the name of agent were initialized in honor to protect and respect their dignity and re putation. 


\begin{tabular}{llllll}
\hline 7 & H. B & GSJST & 550.00 & $\begin{array}{l}\text { Trainee } \\
\text { Captain }\end{array}$ & 7 \\
\hline 8 & H & GSJST & 350.00 & Deck & 9 \\
\hline 9 & I. S & GSJST & 450.00 & Deck & 13 \\
\hline 10 & M & GSJST & 450.00 & Security & 7 \\
\hline 11 & M. A. S & GSJST & 800.00 & Mechanic & 10 \\
\hline 12 & N & GSJST & 500.00 & Wielder & 8 \\
\hline 13 & SF & GSJST & 600.00 & Oiler & 5 \\
\hline 14 & ST & GSJST & 450.00 & Deck & 15 \\
\hline 15 & SG & GSJST & 450.00 & Deck & 9 \\
\hline 16 & SY & GSJST & 450.00 & Deck & 13 \\
\hline
\end{tabular}

Based on data provided in Table 1, there are two agents, initialized BPM and GSJST. The salary is varied, de pends on job division that is related to skill and responsibility, duration of works, and other considerations by the company.

In 2018 there was a relatively similar case to the present case. An IMW initialized S.S reported that he was badly treated, tortured, and faced excessive human mistreatment by R.R until he lost part of his mind and experienced trauma. Besides, there were marks of beating on his body which confirmed the fact. When S.S was not on work schedule, he was forced to work at R.R's house by doing the type of job that was unmentioned in the contract. ${ }^{19}$

Suriname was in "code red" because of the Covid-19 outbreak when the 16 FBC run away to the Indonesian Embassy. ${ }^{20}$ From 4 until 12 June 2020, the Suriname government imposed a total lockdown that caused panic buying in the community that entails an obstacle to getting logistics. This has an impact on the embassy's ability to provide service and protection to those FBC. ${ }^{21}$ The embassy then rented property as a temporary shelter to accommodate the m. ${ }^{22}$

According to the data obtained by the Embassy, IMW that worked for the $\mathrm{CF}$ has been placed since 2015, probably even earlier, and there have been still many cases until 2020. Several employees were detained and compelled to work in the plantation sector since they could not return to their hometowns. There was also a case where some FBC have been accused

19 Ibid.

20 For migrant fish workers, COVID-19 has added another layer of vulnerabilities Their working and living conditions render them vulnerable to transmission of the virus. See Melissa Marschke. et.a1. "COVID-19, instability and migrant fish workers in Asia," Maritime Studies 20 (2021): 87.

21 Supit, loc.cit.

22 Ibid. 
by $\mathrm{CF}$ of causing damage to the company's ships and equipment, although, there was no evidence to back up these claims. CF then decided on pay deduction as a form of compensation. The FBC has declared their notification and reasons before leaving the company, but they were ignored. ${ }^{23}$

\subsection{Function of Indonesian Representatives on Protection of Indonesian Migrant W orker}

Indonesian Embassy in Paramaribo, Suriname is concurrently accredited to the Co-operative Republic of Guyana and the Caribbean Community. ${ }^{24}$ During the Covid-19 pandemic, the embassy facilitated the repatriation of IMW from Suriname and Guyana to Indonesia. ${ }^{25}$

As mentioned in section 2.1, when $16 \mathrm{FBC}$ fled from $\mathrm{CF}$ to the Indonesian Embassy in June 2020, the Indonesian Ambassador and the Embassy's Head of Consular Affairs greeted them. The se 16 FBCs left the CF because they were mistreated and their rights were not respected and fulfilled by the company. They refused to return to $\mathrm{CF}$, fearing that they would be tormented by the owner or management of the company. Therefore, they requested assistance from the embassy to facilitate the return of their passports, the payment of wages, and the return to Indone sia. ${ }^{26}$

It can be assessed that the Indonesian representative in Paramaribo, Suriname has complied with the Vienna Convention on Consular Relations $1963^{27}$ in exercising its consular function when handling the case, especially in protecting, helping, and assisting its national in the receiving State. ${ }^{28}$ In terms of the basic needs of the $16 \mathrm{FBCs}$, the embassy regularly monitors the health condition of the FBC and provides logistics. In facilitating the problem solving, the Embassy has tried to negotiate with $\mathrm{CF}$, but the company was not cooperative. The embassy was informed that the company management cannot meet directly with the representative of the Indonesian Embassy due to the pandemic situation. The Embassy is still working to obtain the travel documents and remaining salary. In doing so, the Embassy has sent notes to the Ministry of Labor and the Ministry of Foreign Affairs of Suriname (MoFA) to inform about the case between 16 Indonesian FBCs and $\mathrm{CF}$. The Embassy has done its utmost to solve the problem through all possible means, including mediation, negotiation, diplomatic channels. Considering the complexity of the cases faced by them, the Embassy decided to hire a lawyer who knows the national law of Suriname. But, as far as the

23 Ibid.

24 The Embassy of the Republic of Indonesia, Paramaribo, the Republic of Suriname, https://kemlu.go.id/paramaribo/en

25 The Embassy of the Republic of Indonesia, Paramaribo, the Republic of Suriname, KBRI Paramaribo Bantu Repatriasi 60 WNI dari Suriname dan Guyana Kembali ke Indonesia, 10 June 2021, https://kemlu.go.id/paramaribo/en/news/13752/kbri paramaribo-bantu-re patriasi-60-wni-dari-suriname-dan-guyana-kembali-ke-indonesia

26 Ibid.

27 The convention has been ratified by Indonesia through Law No. 1 Year 1982 .

28 See Vienna Convention on Consular Relations 1963, Arts. 5a, 5e, and 51. 
authors' knowledge, the case was not submitted before the Suriname court. $^{29}$

The case has not been resolved yet, but both Indonesian Embassy and the 16 FBCs were in constraint to continue to stay in a shelter. The lack of money is the factor that leads the choice to return to Indonesia. To replace their passports that are still being held by CF, on October 6, 2020 the Embassy issued a temporary travel document called Surat Perjalanan Laksana Paspor (SPLP) or a travel document in Lieu of a Passport to the 16 FBCs to be used as a legitimate document to leave Suriname to Indone sia. ${ }^{30}$

Despite the decision of the 16 Indonesian FBCs to leave Suriname, the MoFA has taken action in response to the Indonesian Embassy's report by forwarding it to the Police and Labor Inspectors to be initiated for an investigation. Based on a meeting between the Indonesian Ambassador and the Permanent Secretary for Administrative and Consular Affairs on December 9, 2020, the Suriname government indicated an intention to cooperate in handling the case.

The Indonesian Embassy has also proposed a 'blacklisting' to CF. It filed a report to the Indonesian Ministry of Foreign Affairs, requesting BP2MI (the National Board for the Placement and Protection of Indonesian Migrant Workers) and PJTKI agents no longer send IMW to work for CF. ${ }^{31}$

$\mathrm{CF}$ act to hold the FBC's travel documents, ${ }^{32}$ non-payment of salaries, arbitrary reduction of agreed wage rates, ${ }^{33}$ and beatings ${ }^{34}$ are violated international law and national laws of both Indonesia and Suriname. From a normative sense, CF may be imposed sanctions according to the Protocol of 2014 (P029), in force in Suriname since 3 June 2019 together with the additional guidance provided by R203 Forced Labor (Supplementary Measures) Recommendation 2014 adds considerably more detail concerning access to remedies in cases of forced labor. The P029 refers to both compensation for victims and effective sanctions as follows:

"In giving effect to its obligations under the Convention so suppress forced or compulsory labor, each Member shall take effective measures to prevent and eliminate its use, to provide to victims of protection and access to appropriate and effective

${ }^{29}$ As a comparative view, there was a case in 2018 before Republic of Ireland's High Court where some of the migrant fishermen were believed to have been trafficked and worked under harsh conditions, including being racially abused, underpaid and overworked. See International Organisation for Migration, World Migration Report 2020, Geneva, 2019, 95.

30 Supit, loc.cit.

31 Ibid.

32 See ILO Seafarers' Ide ntity Document Convention (1958) No. 108, Art 3.

${ }^{33}$ See Protection of Wages Convention (1949) No. 95, Art, 8.

34 See Constitution of the Republic of Suriname; Bulletin of Acts and Decrees 1987 No. 166, Art. 15 and 9, Also ILO Forced Labor Convention (1930) No. 29 Art. 2. 
remedies, such as compensation, and to sanction the perpetrators of forced and compulsory labor". 35

This is supplemented by further guidance in R203 relating to access to remedies that requested all to take measures in ensuring all victims of forced or compulsory labor have access to justice and other appropriate and effective remedies, such as compensation for personal and material damages. ${ }^{36}$ In addition, R203 urges member states to strengthen the enforcement of national laws and regulations by giving mandate, resource, and training to the relevant authorities, providing for the imposition of additional sanctions to complement criminal sanctions and guaranteeing the liability of legal persons that committed forced or compulsory labor. ${ }^{37}$

The above articles did not explain examples of any clear attempts by States parties to regulate business activities extraterritorially. However, some countries have extended the geographical scope of criminal law to cover trafficking offenses committed by their nationals extraterritorially (e.g., United Kingdom). ${ }^{38}$ This could be a reference for the Indonesian and Suriname governments in resolving issues related to human rights abuses in a business context, particularly to vulnerable migrant workers.

The Embassy uses ILO conventions as the basis for bilateral agreements and knows that there is no memorandum of understanding (MOU) on the placement and protection of migrant workers. With this convention, migrant workers certainly need not be afraid when their rights at work are threatened, especially if both countries have ratified it, so there are clear rules in the law to protect their rights. Neverthele ss, it is not easy to do so, because there is no proper bilateral agreement to ease the settlement of the case. The importance of the MOU is to establish a monitoring system in which resettlement issues can be better resolved and to prevent migrant workers from becoming victims of any form of injustice.

With the stipulation of new provisions as outlined in Law of the Republic of Indonesia on No. 11 of 2020 concerning Job Creation, ${ }^{39}$ the Indonesian government has generally designed changes that aim to facilitate the establishment of a company for placement of Indonesian migrant workers (P3MI), remembering their position is very crucial in preventing migrant workers from leaving illegally/non-procedural. Lack of education to the workers and pressure from economic factors makes it easy for them to be tempted by the offers made by placement companies. Currently, many

35 International Labour Organization, Normlex, Ratifications of P029 - Protocol of 2014 to the Forced Labour Convention, 1930, Art.1 (1).

36 See R203 - Forced Labor (Supplementary Measures) Recommendation 2014, Art. 12

37 Ibid., Art. 13

38 UNHCR Web, "Business and Human Rights: Enhancing Accountability and Access to Remedy". The most recent CEACR comments on implementation of C029 by the United Kingdom notes that this has been done as part of a series of measures to implement the EU Directive on Human Trafficking, retrieved from https://www.ohchr.org/Documents/Issues/Business/DomesticLawRemedies/Pre liminaryI LOtreaties.pdf accessed on July 2021.

${ }^{39}$ See Law of the Republic of Indonesia on No. 11 of 2020 concerning Job Creation, Art. 57. 
placement companies carry out large-scale recruitment but only prioritize economic goals without paying attention to the procedures and interests of migrant workers. The Indonesian government has stipulated regulations to protect crew members to encourage industry players to be certified through the Ministry of Maritime and Fisheries Affairs Regulation No.2 of 2017 concerning Requirements and Mechanisms Human Rights Certification for Fisheries. This regulation complemented the previous Ministry of Maritime and Fisheries Affairs Regulation No.42 of 2016 concerning Marine Work Agreements for Fishing Boat Crew. ${ }^{40}$

Suriname and Indonesia's ratification of the ILO conventions and the enactment of national regulations seem to become a wonderful law on the text that protects the rights of workers. One of the recent Indonesian legislative products covers the protection of worker's rights to wages, the obligation of employers to provide wages, and the Minimum standard of wages. ${ }^{41}$ The law of Suriname also stipulates the issue of wages, working hours, labor conditions, and special categories of workers, special protection for those engaged in work that requires special effort or who work in unsanitary or hazardous conditions. ${ }^{42}$

Yet there is still much violation of their rights on the ground. The unequal working relationship between employees and employers is obvious. The lack of knowledge and skill ${ }^{43}$ made workers rely too much on their employers. The numerous examples of violation of IMW rights, in particular the present case, demonstrate the incapability of the government has failed to provide complete security and safety, since the recruitment process. This should serve as a lesson learned to the community and migrant workers about the necessity of self-awareness and preparation prior to working overseas.

\subsection{International Labour Organization Conventions Perspective}

FBCs are among the most exploited labor force compared to other sectors of migrants. They are often forced to work very long hours and are paid very cheaply under intense and hazardous working conditions. The profession of FBCs is vulnerable to be exploited. ${ }^{44}$ Their sheer physical

40 Tri Sulistiyono, et. al. "Indonesian Manpower Agency's Responsibility In Fisheries Sector For The Protection Of Indonesian Migrant Workers In Taiwan, "International Journal of Business, Economics and Law 23, No. 1 (2020): 148.

${ }^{41}$ Referring to article 81 (25) of Law No. 11 of 2020 on Job Creation regulates about:

42 The Constitution of the Re public of Suriname, Art. 29.

43 A report revealed that the vanishing fish stocks in territorial seas is a factor why traditional fishermen who have no professional fishing skills become migrant workers. See Organisation for Migration, Indonesian Ministry of Marine Affairs and Fisheries and Coventry University (2016) Report on Human Trafficking, Forced Labour and Fisheries Crime in the Indonesian Fishing Industry. Jakarta, Indonesia, 23.

${ }^{44}$ Kompas News Web, "Eksploitasi Pekerja di Sektor Perikanan Bukan Hal Baru di Indonesia" retrieved from, https:// www.kompas.com/sains/read/2020/05/10/193000323/eksploi tasi-pekerja-disektor-pe rikanan-bukan-hal-baru-di-indonesia. accessed on Fe bruary 2021 
isolation is a factor that contributes to this vulnerability as fishermen are cut off from their fellow citizens, have no access to lawyers, and were not given the most basic medical treatment when working onboard ships. ${ }^{45}$

The ILO Work in Fishing Convention No. 188 of 2007 primarily regulates $\mathrm{FBC}$ protection standards. It governs several aspects of the workforce in the maritime industry, including those who work as FBCs, the responsibilities of fishing boat owners, skippers, and ship crews. It also recognizes the rights of member states to provide protection and exercise law enforcement in the event of a violation of the rights that FBCs should receive while working on fishing boats. Regarding wages, this convention obliged the member states to adopt laws, regulations, or other measures providing those fishers who are paid a wage are ensured a monthly or other regular payment. ${ }^{46}$ Further, Annex II of the ILO Convention 188/2007 states that:

"the fisher's work agreement shall contain the following particulars, except in so far as the inclusion of one or more of them is rendered unnecessary by the fact that the matter is regulated in another manner by national laws or regulations, or a collective bargaining agreement where applicable: (i) the amount of wages, or the amount of share and the method of calculating such share if remuneration is to be on a share basis, or the amount of the wage and share and the method of calculating the latter if remuneration is to be on a combined basis, and any agreed minimum wage".

The $\mathrm{CF}$ did not give a copy of the employment contract to $16 \mathrm{FBCs}$. It is an infringement of the principles of law on contracts based on international private law. Ministry of Manpower should overlook agreements between $\mathrm{CF}$ and FBCs. The relationship between Employers and IMW shall be based on a work agreement that has elements of work, wages, and orders. The contract should also be transparent and are communicated by the government, FBC, and the company. ${ }^{47}$

Regarding the FBCs document that was held by $\mathrm{CF}$, it violated the provisions in the ILO Seafarers' Identity Document Convention 1958 No. 108. The convention regulates that seafarers' identity documents will remain in the hands of seafarers at all times. ${ }^{48}$

The deduction of salary by $\mathrm{CF}$ was also not compatible with the Protection of Wages Convention 1949 No. 95 that stipulates "no deductions shall be permitted only under the conditions and to the extent prescribed regulations or fixed by collective agreement or arbitration award". 49 Having in mind that the deduction was not fair and transparent, considering that all human beings have the right to pursue their material well-being in

45 Chris Armstrong, Abuse, Exploitation, and Floating Jurisdiction: Protecting Workers at Sea*, the Journal of Political Philosophy 0 No. 0 (2020): 2

46 ILO Work in Fishing Convention (2007), No. 188, Art. 23.

47 See also Law of the Republic of Indonesia No.18 of 2017 concerning Protection of Indonesian Migrant Workers, Arts. 14 and 15

48 ILO Seafarers' Identity Document Convention (1958) No. 108, Art, 3.

49 ILO Protection of Wages Convention (1949) No. 95, Art. 8. 
dignity, economic security, and equal opportunity, therefore any unlawful act of deduction of the seamen's wages constitute a violation enunciated by the Universal Declaration of Human Rights 1948.50

FBC notified their reasons for contract termination when they left $\mathrm{CF}$, as required by Article 16150 (SBW), ${ }^{51}$ which states that "the other party immediately communicated the reason for termination." Therefore CF is not accountable for seeking compensation from them. According to $1615 q$ $(\mathrm{SBW})^{52}$, the FBCs may reasonably not anticipate their job to be prolonged due to urgent reasons/grounds or serious misconduct, and their act of decamping, which can be regarded as a ground of justification, cannot be blamed for the attribution of their act.

It is a constitutional guarantee in Suriname that everyone has a right to physical, mental, and moral integrity. The Constitution of the Republic of Suriname also ensures no one may be subjected to torture, degrading, or inhumane. ${ }^{53}$ The abusive and unlawful acts by CF in the territory of Suriname violated the Constitution of the Republic of Suriname, ${ }^{54}$ as well as the ILO Private Employment Agencies Convention 1997 No. 181,55 in relation to freedom of association, minimum wages, working time, and other working conditions, access to training, occupational safety and health and protection of workers claims as mentioned in the provision. It may also be referred to the ILO Forced Labor Convention, 1930, No. 29 that defines forced or compulsory labor as "all work or service which is exacted from any person under the menace of any penalty and for which the said person has not offered himself voluntarily" 56 and the Abolition of Forced Labor Convention 1957 No. 105 that urges the states to undertake to suppress and not to make use of any form of forced or compulsory labor. ${ }^{57}$ Lastly, the failure of the owner of $\mathrm{CF}$ to provide decent work and living conditions on board is also incompatible with Convention No. 188/2007. 58

\section{CONCLUSION}

Workers are frequently subjected to abuse because they are perceived as lacking in work abilities; this is due to a lack of preparation before traveling abroad. It is important to provide information and instruction about the fundamentals of knowledge prior to working abroad. It is expected that in case of a breach of rights by the foreign company where the workers

\footnotetext{
50 See the Universal Declaration of Human Rights (1948), Art. 23.

51 See Surinams Burgerlijk Wetboek, Art. 16150.

52 Ibid., Art. 1615q.

53 See Constitution of the Republic of Suriname; Bulletin of Acts and Decrees 1987
} No. 166, Arts. 9 and 15.

54 Ibid., Arts. 9, 15, and 29.

55 See Private Employment Agencies Convention (1997) No. 181, Art 11.

56 See ILO Forced Labor Convention (1930) No. 29, Art. 2.1.

57 ILO Abolition of Forced Labor Convention (1957) No. 105, Art. 1.

58 ILO Work in Fishing Convention (2007), No. 188, Art. 11. 
are employed, they will have a proper understanding of the procedure to defend their rights and get what they deserved to get.

With regards to the case of 16 IMW who worked at a company in Suriname, the company is strongly alleged to breaching the employment contracts and violating law and regulations of the Republic of Suriname as well as many international treaties, particularly the International Labour Organization (ILO) conventions. Indonesian Representatives in Paramaribo, Suriname have conducted some efforts to facilitate and assist the advocation of their rights through all possible means, including mediation, negotiation, and diplomatic channels, but the results seems not to be succeded yet.

To prevent asimilar case in the future, Indonesia and Suriname should create a Memorandum of Understanding (MoU) on the protection of migrant workers. The MoU shall comply with ILO conventions that are ratified by the two states and other relevant international treaties that cover the protection of the rights of the migrant workers.

\section{BIBLIOGRAPHY}

\section{Book}

Soekanto, Soerjono. Pengantar Penelitian Hukum. Jakarta: UI Press, 1984

\section{Journal Article}

Armstrong, Chris. "Abuse, Exploitation, and Floating Jurisdiction: Protecting Workers at Sea*, the Journal of Political Philosophy 0 No. 0 (2020): 1-23. doi: https://doi.org/10.1111/jopp.12238

Banu, Lukas. "Implementasi Hukum Pasal 35 UU No. 39 Tahun 2004 dalam Program Recognized Seasonal Employment”, Jurnal Magister Hukum Udayana 7, No. 1 (2018): 92

Koesrianti. "Perlindungan Hukum Pekerja Migran PLRT Di Luar Negeri Oleh Negara Ditinjau Dari Konsep Tanggung Jawab Negara", Yustitia 4, No. 2 (2015): 249. doi: http: //repository.unair.ac.id/id/e print/96185

Marschke, Melissa, et al." COVID-19, instability and migrant fish workers in Asia." Maritime Studies 20, (2021):87-99. https://doi.org/10.1007/s40152-020-00205-y

Ratihtiari, Titah A.A. and I Wayan Parsa, "Perlindungan Hukum Terhadap Pekerja Migran Indonesia Di Luar Negeri". Kertha Semaya 7, No. 7 (2019) doi: https://ojs.unud.ac.id/index.php/kerthasemaya/article/view/5012 $\underline{9 / 29846}$

Sulistiyono, Tri, et. al. "Indonesian Manpower Agency's Responsibility In Fisheries Sector For The Protection Of Indonesian Migrant Workers In Taiwan", International Journal of Business, Economics and Law 23, No. 1 (2020): 144-150.

Valensy, Cici. "Peran International Labor Organization (ILO) Dalam Melindungi Buruh Migran Indonesia di Arab Saudi Tahun 20122016", Jurnal Online Mahasiswa FISIP 4 No. 2, (2017): 5-7. doi: https://jom.unri.ac.id/index.php/JOMFSIP/article/view/16335/15 $\underline{800}$ 
Wahyudi, Tri Denny. "Perlindungan Hukum Terhadap Tenaga Kerja Indonesia Di Luar Negeri", Jurnal Ilmu Hukum, (2015): 170-184. doi: https://doi.org/10.30996/mk.v0i0.2118

Wijayanti, Henni and Arovah Windiani. "Legal Protection and Advocacy for Indonesian Migrant Workers", Jurnal Universitas Muhammadiyah 1, No. 12017$)$ (2005. 100 doi: https://jurnal.umj.ac.id/index.php/IMC/article/view/1300/1171

\section{Legal Documents}

Indonesia, the 1945 Constitution of the Republic of Indonesia.

Indonesia, Law No.18 of 2017 concerning Protection of Indonesian Migrant Workers.

Indonesia, Law No. 11 of 2020 concerning Job Creation.

Indonesia, Ministry of Maritime and Fisheries Affairs Regulation No.2 of 2017 concerning Requirements and Mechanisms Human Rights Certification for Fisheries.

Indonesia, Ministry of Maritime and Fisheries Affairs Regulation No.42 of 2016 concerning Marine Work Agreements for Fishing Boat Crew .

Suriname, Constitution of the Republic of Suriname; Bulletin of Acts and Decrees 1987 No. 166.

Suriname, Surinams Burgerlijk Wetboek.

International Convention on the Protection of the Rights of All Migrant Workers and Members of their Families.

International Labour Organization, Forced Labor Convention 1930, No. 29

International Labour Organization, Seafarers' Identity Document Convention 1958, No. 108.

International Labour Organization, Protection of Wages Convention 1949, No. 95.

International Labour Organization, Forced Labor (Supplementary Measures) Recommendation 2014.

International Labour Organization, Work in Fishing Convention 2007, No. 188.

International Labour Organization, Abolition of Forced Labor Convention 1957, No. 105.

Vienna Convention on Consular Relations, 1963.

Vienna Convention on The Law of Treaties, 1969.

Universal Declaration of Human Rights, 1948.

\section{Other Document}

Organisation for Migration, Indonesian Ministry of Marine Affairs and Fisheries and Coventry University (2016) Report on Human Trafficking, Forced Labour and Fisheries Crime in the Indonesian Fishing Industry. Jakarta, Indonesia

International Organisation for Migration, World Migration Report 2020, Geneva, 2019. 


\section{Interview}

Supit, Michael Bastian. Head of Protocol \& Consular, Indonesia Embassy in Paramaribo-Suriname. "Protection of Migrant Workers in Suriname: How do Indonesian Representatives Implement ILO Conventions?" Interview by Lutecia Wibisono, Suriname, December 18, 2020.

\section{Website Content}

International Labour Organization, Normlex, Ratifications of P029 - Protocol of 2014 to the Forced Labour Convention, 1930, https://www.ilo.org/dyn/normlex/en/f?p=NORMLEXPUB:11300:0:: NO:11300:P11300_INSTRUMENT_ID:3174672:NO accessed on 29 June 2021.

Kompas News Web, "Eksploitasi Pekerja di Sektor Perikanan Bukan Hal Baru di Indonesia”. https://www.kompas.com/sains/read/2020/05/10/193000323/eks ploitasi-pekerja-di-sektor-perikanan-bukan-hal-baru-di-indonesia.

Office of the United Nations High Commissioner for Human Rights, "Status Of Ratification Interactive Dashboard," International Convention on the Protection of the Rights of All Migrant Workers and Members of their Families, https://indicators.ohchr.org/

International Labour "ILO Global" http://www.ilo.org/global/What_we_do/Publications/lang-en/contLang--id/docName WCMS_098256 / index.htm

International Labour Organization, "Labour Migration", https://www.ilo.org/global/topics/labour-migration/lang-en/index.htm

International Labour "What We Do" http://www.ilo.org/global/What_we_do/Publications/lang-en/contLang--id/docName WCMS_098256/index.htm

International Labour Organization, Normlex, Ratification by Country, "Ratifications for Indonesia", https://www.ilo.org/dyn/normlex/en/f?p=1000:11200:0::NO:11200: P11200_COUNTRY_ID:102938

International Labour Organization, Normlex, Ratification by Country, "Ratifications for Suriname". https://www.ilo.org/dyn/normlex/en/f?p=1000:11200:0::NO:11200: P11200_COUNTRY_ID:103287

The SBMI Official Web, "ILO Conventions That Have Been Ratified by The Government of Indonesia" http://sbmi.or.id/2018/05/konvensi-iloyang-telah-diratifikasi-oleh-pemerinah-indonesia/

UNHCR Web, "Business and Human Rights: Enhancing Accountability and Access to Remedy". The most recent CEACR comments on implementation of $\mathrm{C} 029$ by the United Kingdom notes that this has been done as part of a series of measures to implement the EU Directive on Human Trafficking. https://www.ohchr.org/Documents/Issues/Business/Dome sticLaw Remedies/PreliminaryILOtreaties.pdf 